\title{
The Christian Profile of Caritas in Slovakia from the Point of View of Its Employees Jozef Žuffa
}

\section{Introduction}

Charity is theologically understood as the activity of the community and the whole Church in the sphere of spiritual care, as well as in the sphere of special and organised charitable activity. ${ }^{1}$ It is therefore possible to claim that the issue of whether an ecclesial community has the right to be called 'Christian' or 'Catholic' is from the theological point of view co-determined by whether social engagement is realised within it. Charity, which performs the service of helping love, is not merely a private Christian obligation, but an essential mark of the whole Church and an inseparable element of pastoral activity. Among its tasks belongs the analysis of the structural contexts of the present need, as well as the political interventions implied in it. The forms of realising the service are not given in advance; they rather tend to change with changing social conditions. What organisational forms charity takes in a certain country is therefore not merely determined by faith, but also by the social and socio-political circumstances. Charitable organisations corresponding to different social and political milieus have also found different forms of being grounded in ecclesial life.

According to its own yearbook, Slovak Catholic Caritas, named Caritas Slovakia in English, employs more than 1500 persons in its facilities and projects throughout the country, ${ }^{2}$ which makes it the largest provider of social services in Slovakia. At the same time, it is an ecclesial organisation, which also provides space for pastoral work. But charitable engagement is connected with the viability of the ecclesial communities within which it is realised.

Besides the theological starting points, the profile of Caritas is also formed by the organisational culture, which is individually specific to each organisation across the different sectors of society. The profile of an organisation constituted by human beings - its present employees, their values, and the way they perceive their employer is co-formed by the institution's pre-defined mission and vision. How the Slovak Catholic Caritas is perceived by its employees is the object of investigation in this study, with the goal of identifying the image of its Christian profile.

Cf. Henrich POMPEY and Paul-Stefan ROSS, Kirche für andere. Handbuch für eine diakonische Praxis, Mainz: Grünewald, 1998, p. 148. Cf. @ S SLOVENSKÁ KATOLÍCKA CHARITA, Výročná správa (on-line), at: http://charita.sk/docs/pdf/rocenka_2015.pdf, p. 31, accessed $15^{\text {th }}$ October 2016. 


\section{Methodological observations}

The paper is based on a qualitative investigation, which has helped us to focus more intensely on the investigated topic. The investigation was carried out over the course of summer term 2015/2016 as part of the seminar 'Qualitative Research' at the Faculty of Theology of the University of Trnava. No variables or hypotheses were stipulated at the beginning of the investigation; the author of the paper with the students worked out sets of questions. Then the respondents were selected, all of whom work in the facilities of Caritas Slovakia. The respondents were selected from different parts of Slovakia: seven of them are employees in managerial positions, four are workers in executive functions, and one is a volunteer. The dates were arranged and the twelve interviews undertaken by the students themselves. The three pre-prepared sets of questions concerned the perception of Caritas's Christian profile, the style of personnel management, and the organisation culture.

The interviews took place in calm environments, where the respondents were presented with the sets of questions in turn, which were supplemented with other questions if a respondent deviated markedly from a set. The interviews took 25 to 40 minutes. The answers were recorded on mobile phones and later transcribed.

The transcribed texts were then together divided into segments using open coding, where the segments concerned topic-identical categories, and then the statements were searched for meanings using axial coding. ${ }^{3}$ For the topic focus of this paper, I have selected only that part of the coded statements that concerned the perception of Caritas's Christian profile. When quoting the individual respondents, I do not give their name or work position, since the accumulated statements are evaluated as equal and the respondents are understood as a uniform group.

\section{Interview results}

Caritas is a Church-operated organisation through which the Catholic Church realises its mission of serving the neighbour. In interviews with senior workers at different levels, it was confirmed that the spectrum of perceiving Caritas and its tasks is very broad. We cite several answers:

'Caritas in Slovakia is a confederation of legal subjects, which means that the diocesan and archdiocesan Caritas are separate legal subjects who organise their own work and plan the content and the essential things. This confederation constitutes Caritas Slovakia, which is not superordinate [to them] but coordinates those things that are [in their] common interest. And besides that, it also runs charity homes, humanitarian aid from abroad, etc.'

The director of a charitable facility for the elderly describes how the home came to be: 'Our facility began in 1998 as a soup kitchen. Until 2003 we had a problem obtaining clients, but since then I have two or three times as many applications as I can accept clients. The trust in this service has grown very much, as well as the need for such a facility. People are even waiting for someone to die, so there will be a free place. It is also because many young people have gone away in search of work and there is no one to look after their older kin. [...] I perceive the fact that diocesan Caritas organisations have become independent as a highly beneficial step in the development. Insofar as the conditions are different in the individual regions, each Caritas can react adequately to the requirements and needs. In the first place Catholic Caritas is a specific provider of services to the dependent and needy

3 Cf. Roman ŠVAŘÍČEK and Klára ŠEĎOVÁ, Kvalitativní výzkum v pedagogických vědách, Praha: Portál, 2014, p. 384. 
regardless of religious confession. And the service is not just a matter of philanthropy; it is primarily a service of love to those in need, in the sense of Jesus' words: As you did it to one of the least of mine, you did it to me.'

A volunteer in a parish Caritas describes the beginning of their work: 'It started when the new parish priest came here who set up the parish council. The parish priest before was smart and did not need a parish council. And since the present parish priest is also smart, I would perhaps say even smarter, he delegated many activities to the parish council so that he has more time for the spiritual things. So, for me this is an organisation which is developing, is still seeking its path, has the good intention to do social work with a Christian aspect, which means also with care for the mental and spiritual aspect of the human being. [...] It has its back-up projects, it is a net-forming organisation, which means that it aspires to get to the people also in the smaller villages. And I think that it still has many tasks to complete in order to be accepted by the public.'

Another respondent's statement points out that Caritas also works in spheres which are unattractive for social services: 'The main focus of our Caritas is care of the homeless, ill, old and dying. Never in my life have I felt inspired to do, for example, projects for children in Bratislava, you know why? I can imagine that for projects for children you get a whole lot of money, which is why the issue of children is covered in this city. And there is not sufficient care for the elderly and we can give it even more than the other institutions do. So, the mission of Caritas is that you simply go and work in those spheres where the service is insufficient or where the service does not exist at all.'

In the sphere of being efficacious between social policy and economic policy, it is always possible to speak about the need to bring these 'two worlds' closer together. That can only happen in the case of an opinion exchange between leading political and economic representatives and social workers. Caritas is also perceived as an intermediary between the world of politics and the social reality of marginalised groups. 'In parliamentary committees, we have talked to all and we have commented on the social spheres and the law about social help, the hospice issue, the basics in healthcare. I wouldn't say that politicians always address us. Sometimes they address the platform, the whole spectrum of the social sphere, and we then communicate to find a common position,' one of the respondents explains the connection between Caritas and the world of politics. A similar 'bringing together different worlds' can also be perceived in the perception of the issue of the religious dimension of Caritas. First of all, the president of Caritas in Slovakia is a bishop and, according to the director of one facility, he is responsible for representing it and also for spiritual formation in it. According to one employee, this also clearly implies the religious character of the Caritas organisation. 'I think that a Caritas worker ought to be religious. If there is to be more than just an employee approach to the dependent and the poor, he must be religious. If he is to perceive the poor as an image of Christ and his service is to be a service to Christ, it is not possible without faith. He can be a decent, good human being, but it is not possible in a charitable service. The religious character of Caritas can certainly be perceived. And when we had a bulletin board there, we always designed it with a religious dimension, perhaps when there was some religious time, for example, Lent.'

Another respondent points out the specific fact that his employer allows him to address issues of faith at work: 'He is not a person who directly influences Caritas, but we have one clergyman who helps with the work in the sphere of spiritual care. People also need to talk about faith.' 
Another interviewee points out a less positive dimension of connecting work with faith: 'A dimension of the organisational and internal structure also is that an ecclesial office, namely the episcopal office, decides about senior and junior employees. That is why it is difficult to imagine the separation of this social sphere from ideological activity. There must be loyalty, but that is in all organisations, I wouldn't find fault with that. But sometimes that loyalty is not primary for the work, but loyalty is primary with respect to ideology, that it is in a certain way an instrument of propaganda, not social work.'

Concerning the issue of understanding Caritas as a civic institution, one respondent said: 'With this topic we return to the basic question of what is theological in the essence of a charitable service and whether we can perhaps agree that the minimal space between charity with a Christian motivation and charity with a secular motivation is humanism. If there is humanism in the space between secular and ecclesial charity, then there ought to be no essential difference between them. And if there is no difference, then the question is what is the added value. That means that the added value can consist, for example, in that we not only provide the basic service but also evangelise. Or it can be that as a result of willingness towards personal sacrifice, Caritas has lower worker costs and so there is more money left for the charges or protégés. [...] The motivation of people for working in Caritas depends on the social structure of the particular country. So, it is a different matter when someone is willing to work as a helper in a children's home in Spiš for minimal wages, because she will not find other employment there, and when someone is willing to work in a Caritas in Germany for a lower salary than he would get in a similar secular facility.'

'I think that the Christian element can be perceived more in the spirit and the atmosphere,' another employee states. 'With us it is clear that we are a Christian organisation, the Christian spirit is difficult to generalise, it depends on the individual facility. And the state of Caritas anywhere depends on the state of the Church there. It is because insofar as people live their active lives as Catholics, so they can also proceed in this service. Sometimes our people lack awareness of this traditional Christianity, which can be perceived, so that they could adapt it to the present time and to what the person momentarily needs. For that we certainly lack formation. If we went to the East or in this whole region, so compared to the Czech Republic we have a higher percentage of Christian population, but the Czech Republic does a lot more than we do, although fewer Christians work in Caritas there.'

A Caritas employee has a practical view of the difference between Caritas and a civic institution: 'There is a great difference as compared to a hospital. Of course, there are also differences between hospitals. When I went to shave one client, I had to visit almost all the patients because there was no one to take care of them. When we had a client here, we knew that he ought to be showered, washed... He went to a hospital and when we left him there for a week we found him bearded like Moses. He was not showered, not shaved, not washed, nothing. We had to go there to give him showers. In hospital the people change, the clients are there for a week, so a nurse need not even know much about the clients. In Caritas there are people who do not leave quickly. When visitors come, I know perfectly well who they are coming to visit. So, there is a different relationship in Caritas than in a hospital.'

There are different motivations for working in Caritas. A leading worker describes her own: 'As I understand it, the reason for my work is my faith and my Christian life. I deem it good and I know that I can give people something from my internal resources and I feel that it is precisely for these social spheres. Imagine that a 25-year-old young man with a university education comes, he is a doctor, 
and he works as a 'bell boy' in a social centre for the homeless. Some people seem to come here to do a service from an internal motivation, willing to give a piece of their life to others.'

'With the spiritual dimension of the formation of workers, volunteers and clients in Caritas, it is necessary to deal with spiritual formation. For example, in Spis there is a priest entrusted with this kind of care for the employees and clients of Caritas in Spiš. The situation is similar in the Greek Catholic diocesan Caritas in Prešov. In the other ones, it is currently being dealt with, so that every diocesan Caritas would have its priest who would work on developing the charism of the service,' claims one of the respondents concerning the issue of the formation of workers in Caritas organisations.

An employee explains the way workers are trained in Caritas: 'Employee development is closely connected with the quality of provided services and at the same time it also belongs to the organisation culture. Caritas is not aware of this precisely because it bases that company culture on religious servility. So hence the need for spiritual guidance. In this, Caritas is lacking because there is no formation of our people in this sphere.'

\section{Synthesis of results}

The interviews undertaken with employees of Caritas Slovakia present the way several spheres are perceived. The respondents' answers make it possible to identify a broad spectrum of the ways they perceive the Christian profile of their employer. The statements can be summarised into three positive strands of meaning of the Christian profile.

- In providing social services, an important part is played by spiritual care - 'social work with a Christian aspect, and also with care for the mental and spiritual aspect of the human being.

- The addressed respondents perceive the Christian profile in the added value as compared to other organisations in the flexible offer of services, according to present needs: 'we can give it even more than the other institutions do. [...] you work in those spheres where there the service is insufficient or where the service does not exist at all.

- Through the connection with the structure of the Catholic Church the organisation can access all regions and due to cooperation with parishes it is network-forming - 'that is another reason why we became a partner for the ministry, because we have an all-Slovak coverage.'

The weak points of the Christian profile are declared in two spheres.

- compensating for quality 'only' with prayer to solve the client's problems.

- creating an atmosphere in which the employees attend prayer programmes only in order to 'survive', i.e., insufficient emphasis on a Christian style of thinking which is replaced by formal religious displays - 'Caritas [...] bases its company culture on religious servility. So hence the need for spiritual guidance,' 'employees learn to sing religion-tinged songs, in order to conjure up a smile on the faces of their superiors'.

The most important outcome of the research seems to be the need for continually updating Christian values so that they would not be intelligible merely for a narrow group of people who have long been socialised in them and reflexively realise them. This need is pressing not only with respect to the external environment, but also within the organisation it is necessary to honestly reflect on what the Christian worldview means for the organisation's activity. The goal of such 
reflection is that the organisation of Caritas can become a manifestation of practical theology in the dynamics of the needs of the poor. The organisation of the Church-operated Caritas, which wants to be close to human need, clearly depends on the present state of society and its difficulties: 'For the theology and practice of Caritas this implies that the Church is diaconic-charitable by its dimension, not determining by itself which direction it will take, but allowing its path to be determined by those to whom it ought to be close. This holds primarily so that it takes the needs of people (and also of creation) seriously and truthfully in all its various forms and contexts.'

\title{
The Christian Profile of Caritas in Slovakia from the Point of View of Its Employees
}

\begin{abstract}
Serving the neighbour is an important pillar of the identification of ecclesial life and Christian identity. One of the platforms for realising it is the organisation of Caritas, active worldwide, which operates in Slovakia under the name Caritas Slovakia. The paper examines the way Caritas employees perceive its Christian profile through semi-structured interviews. The research aims to present the variability and contents of the Christian dimension of Caritas from the point of view of selected respondents. The results show the respondents' perceptions in the sphere of spiritual care for the clients and of a flexible offer of services according to the neighbours' present needs.
\end{abstract}

Keywords: Caritas Slovakia, profile, Christianity, organisation, employees

\author{
Author contact \\ Dr. Jozef Žuffa \\ Faculty of Theology, University of Trnava in Trnava \\ Kostolná 1, 81101 Bratislava \\ jozef.zuffa@truni.sk
}

4 Norbert METTE, Theologie der Caritas, in: Markus LEHNER et al. (ed.), Grundkurs Caritas, Linz: Landesverlag., 1993 , p. 134. 